\title{
BMJ open EGFR status in oral squamous cell carcinoma: comparing immunohistochemistry, FISH and CISH detection in a case series study
}

To cite: Bernardes VF, GleberNetto FO, Sousa SF de, et al. EGFR status in oral squamous cell carcinoma: comparing immunohistochemistry, FISH and $\mathrm{CISH}$ detection in a case series study. BMJ Open 2013;3:e002077. doi:10.1136/ bmjopen-2012-002077

- Prepublication history for this paper are available online. To view these files please visit the journal online (http://dx.doi.org/10.1136/ bmjopen-2012-002077).

Received 19 September 2012 Revised 21 December 2012 Accepted 3 January 2013

This final article is available for use under the terms of the Creative Commons Attribution Non-Commercial 2.0 Licence; see http://bmjopen.bmj.com

For numbered affiliations see end of article.

Correspondence to Dr Maria Cássia Ferreira Aguiar; cassiafa@ufmg.br

\section{ABSTRACT}

Objectives: To compare the immunohistochemistry (IHC) expression of epidermal growth factor receptor (EGFR) in oral squamous cell carcinomas (OSCC) with the gene amplification evaluated by fluorescence in situ hybridization (FISH) and chromogenic in situ hybridization (CISH) and their association with clinicopathological parameters. Additionally, we tested the sensibility and specificity of CISH in comparison with FISH.

Design: Case series study

Setting: Oral surgery and pathology department in a school of dentistry.

Participants: 52 patients with histopathological diagnosis of OSCC

Methods: Tumour tissue samples from 52 patients with OSCC were evaluated by IHC, FISH and CISH using tissue microarray technology. Clinicopathological data from all patients were collected.

Results: EGFR+ rates were $53.8 \%$ (28/52) by IHC, $5.8 \%$ $(3 / 52)$ by $\mathrm{CISH}$ and $15.4 \%$ (8/52) by FISH. Amplification detected by $\mathrm{CISH}$ and FISH with IHC negative occurred in $3.8 \%(2 / 52)$, and one case (1.9\%) showed amplification detected by $\mathrm{CISH}$ and FISH and protein overexpression concomitantly. There were $9.6 \% \mathrm{FISH}+$ cases with IHC and $\mathrm{CISH}$ negative rates and $6 / 8(75 \%) \mathrm{FISH}+$ and also EGFR+ cases; however, an association between protein expression and gene amplification was not found for both techniques. IHC and FISH rates were not associated with clinicopathological features. $\mathrm{CISH}+$ rates were associated with T3-T4 status. Compared with FISH assay, $\mathrm{CISH}$ reached a sensitivity of $37.5 \%$ and specificity of $100 \%$.

Conclusions: There is no association between EGFR expression and gene amplification in OSCC when the IHC is driven to external epitopes of the protein. Although $\mathrm{CISH}$ demonstrates specificity, technical problems may influence sensibility when compared with FISH.

\section{INTRODUCTION}

Epidermal growth factor receptor (EGFR) signalling participates in the regulation of

\section{ARTICLE SUMMARY}

Article focus

- This study compares immunohistochemistry, chromogenic in situ hybridization (CISH) and fluorescence in situ hybridization (FISH) in the evaluation of epidermal growth factor receptor (EGFR) status in oral squamous cell carcinoma (OSCC). It shows that there is no association among these methods and discusses the limitations of each of them.

- The authors suggest that other mechanisms that alter the protein expression, which are not related to amplification, need to be investigated in OSCC.

\section{Key messages}

- There is no association between EGFR expression and gene amplification in OSCC when the immunohistochemistry is driven to external epitopes of the protein.

- Although CISH demonstrates specificity in these samples, technical problems may influence sensibility when compared with FISH.

Strengths and limitations of this study

- The strength of this study is the comparison among three standardised methods of EGFR investigation. This signalling is becoming attractive in the therapy of head-and-neck squamous cell carcinoma.

- The following limitation should be considered: preanalytical factors might have influenced the signal intensity of $\mathrm{CISH}$.

cell proliferation and differentiation during development and, in tumour cells, contributes to proliferation, invasion and metastasis formation. $^{1}{ }^{2}$ It is frequently expressed in many types of cancer including the head-and-neck squamous cell carcinoma (HNSCC). As its overexpression is frequently associated with poor clinical outcome, the receptor is becoming attractive in the therapy of this neoplasm. ${ }^{3} 4$ 
Comparative studies of EGFR detection by immunohistochemistry (IHC) and fluorescent in situ hybridization (FISH) have shown a high concordance rate. Chromogenic in situ hybridization (CISH) was introduced a few years ago as an alternative to FISH in view of some advantages, such as evaluation in the conventional bright-field microscopy system, permanent record and preserved morphological features. ${ }^{5}{ }^{6}$ However, to date, no studies have been published regarding EGFR copy numbers detected by FISH concomitant to CISH and the evaluation of this protein expression in oral squamous cell carcinoma (OSCC).

The objective of this study was to investigate the profile of expression of EGFR protein and correlate this finding with the gene status evaluated by two methods of hybridization (CISH and FISH) in tumour samples of OSCC. Clinicopathological parameters were also included in the evaluation of the tumours. Additionally, the accuracy of CISH has been compared with FISH.

\section{MATERIALS AND METHODS \\ Patients' eligibility}

Patients with a histopathological diagnosis of OSCC were enrolled in this study. Clinical data, such as age, gender, symptoms, location and extension of the tumour, nodal involvement and tobacco and alcohol habits, were obtained from medical records. The tumour samples were obtained from incisional biopsy before any adjuvant therapy.

This study was approved by the local Research Ethics Committee, and a signed, informed consent was obtained from all participants.

\section{Immunohistochemistry (IHC)}

IHC for the detection of the EGFR antigen was performed using the monoclonal antibody clone 31G7 (Zymed Laboratories Inc, San Francisco, California, USA) and sections of oral mucosa were used as positive control. Briefly, $4 \mu \mathrm{m}$ sections were plated on histological slides treated with 3-aminopropyltriethoxy-silano, followed by the deparaffination, hydration and blocking of intrinsic enzymatic activity. Slides were then immersed in pepsin $10 \%$ at $37^{\circ} \mathrm{C}$. After washing in distilled water, sections were subsequently incubated in the primary antibody (1:100 dilution) at room temperature for $60 \mathrm{~min}$. After rinsing in Tri-HCl buffer, sections were incubated for $30 \mathrm{~min}$ at room temperature with biotinylated multilink swine antigoat, mouse and rabbit immunoglobulin (LSAB Kit, DaKo, Carpinteria, California, USA). The reactions were revealed by applying 3,3'-diaminobenzidine (DAB) in chromogen solution (Dako; Carpinteria, California, USA). The sections were counterstained with Mayer's haematoxylin and mounted in Permount (Fisher Scientific; New Jersey, USA). Semiquantitative assessment of the immunohistochemical stain results were performed by a pathologist who was unaware of the clinicopathological details and the gene amplification status. EGFR expression was evaluated according to a previously defined four-point scale based on the immunolabelling of tumour cell membranes proposed by Diniz-Freitas $e t a l^{7}$ as follows: 0 (no labelling or labelling in $<10 \%$ of tumour cells); (1) (weak labelling, homogeneous or patchy in $>10 \%$ of the tumour cells); (2) (moderate labelling, homogeneous or patchy in $>10 \%$ of the tumour cells); (3) (intense labelling, homogeneous or patchy in $>10 \%$ of the tumour cells). These scores were subsequently grouped into two categories: negative ( 0 or 1$)$ and positive labelling ( 2 or 3$)$.

\section{Tissue microarray (TMA)}

Representative core tissue sections of strong immunoexpression of EGFR were taken from paraffin blocks from each patient and arranged in a new tissue microarray (TMA) block using the Manual Tissue Arrayer (Beecher Instruments, Silver Spring, Maryland, USA). As previously suggested by Monteiro et al ${ }^{8}$, we selected the area of interest avoiding necrosis and keratin pools. In the negative cases, a representative area of the tumour was selected considering the histological graduation. One core with $1 \mathrm{~mm}$ diameter was used from each sample. In an attempt to perform both FISH and CISH assays, $4 \mu \mathrm{m}$ thick sections were obtained.

\section{Fluorescent in situ hybridization (FISH)}

A Zytolight Spec EGFR/CEN 7 Dual Color Probe (Zytovision, Bremerhaven, Germany) was used to perform FISH. After deparaffinisation in two rinses of $100 \%$ xylene for $5 \mathrm{~min}$ each, the slide was rehydrated through two rinses of $100 \%$ alcohol for 5 min each. Next, the slide was treated with $0.2 \mathrm{mmol} / 1 \mathrm{HCl}$ for $20 \mathrm{~min}$, distilled water for $2 \mathrm{~min}$ and $2 \times$ standard saline citrate for $3 \mathrm{~min}$. The slide was submitted to the pretreatment buffer (Saline-sodium citrate (SSC) buffer: $0.3 \mathrm{mmol} / 1$ sodium chloride and $0.03 \mathrm{mmol} / 1$ sodium citrate) for $30 \mathrm{~min}$ at $82^{\circ} \mathrm{C}$ in a water bath and then for $36 \mathrm{~min}$ at $37^{\circ} \mathrm{C}$ in the protease digestion in protease buffer $(0.05 \mathrm{mmol} / 1$ Tris- $\mathrm{HCl}$ at $\mathrm{pH} 7.8,0.01 \mathrm{mmol} / 1$ ethylene diamine tetra-acetic acid and $0.01 \mathrm{mmol} / \mathrm{l}$ $\mathrm{NaCl})$. Finally, the slide was placed in $10 \%$ formalin in phosphate-buffered saline (PBS) for $10 \mathrm{~min}$. Dehydration was performed in 70, 85 and $100 \%$ ethanol, consecutively. Both FISH probes and target DNA were denatured simultaneously for $5 \mathrm{~min}$ at $75^{\circ} \mathrm{C}$ and incubated overnight at $37^{\circ} \mathrm{C}$. For signal detection, the slide was placed in the posthybridization wash buffer (SSC and NP40) for $3 \mathrm{~min}$ at $74^{\circ} \mathrm{C}$ and counterstained in $2 \times \mathrm{SSC} / 0.03 \mu \mathrm{g} / \mathrm{ml}$ 4,6-diaminido-2-phenylindole dihydrochloride for the identification of the nucleus.

\section{Chromogenic in situ hybridization (CISH)}

CISH was performed on $4 \mu \mathrm{m}$-thick formalin-fixed, paraffin-embedded tumour samples. Briefly, tissues were deparaffinised in xylene and immersed first in ethanol and later in CISH Tissue Heat Pretreatment Solution (Invitrogen Corporation, Camarillo, California, USA) at 
$98^{\circ} \mathrm{C}$ for $21 \mathrm{~min}$. The slides were immediately washed with distilled water for 2 min. Enzymatic digestion was performed by incubating sections within pepsin for $10 \mathrm{~min}$ at room temperature. The slides were then washed, dehydrated with graded ethanol and air-dried. A ready-to-use Spot-Light EGFR probe (Invitrogen) $15 \mu \mathrm{l}$ was applied to the coverslips, which were placed on the sections, and the edges were sealed. The slides were denatured on a hot plate $\left(94^{\circ} \mathrm{C}\right)$ for $5 \mathrm{~min}$ and hybridization was performed overnight at $37^{\circ} \mathrm{C}$ in a humidified chamber (Dako Hybridizer:Dako, Carpinteria, California, USA). A stringent wash was performed with $0.5 \times$ standard saline citrate at $75^{\circ} \mathrm{C}$ for $5 \mathrm{~min}$; a PBS/ Tween 20 wash was performed twice for $2 \mathrm{~min}$. Sections were blocked with $3 \% \mathrm{H}_{2} \mathrm{O}_{2}$, diluted with methanol for $10 \mathrm{~min}$ and PBS wash was performed twice for $2 \mathrm{~min}$. The unspecific staining was blocked by applying the Cas-Block (Spot-Light CISH detection Kit) and by incubating for $10 \mathrm{~min}$. After incubation with a Mouse anti-Dig antibody for $30 \mathrm{~min}$ at room temperature, the procedure was continued by incubation with a polymerised HRP-antimouse antibody and substratechromogen solution (DAB) for $30 \mathrm{~min}$ at each step and counterstained with haematoxylin for $5 \mathrm{~s}$. The tissues were dehydrated in ethanol and coverslipped in Tissue-Tek Prisma/Film (Sakura Finetek Inc, Torrance, California, USA). The Spot-Light chromosome 7 centromeric probe has been used to check for polysomy (Invitrogen).

\section{Evaluation of CISH and FISH results}

Gene status was determined according to the manufacturer's criteria and classified in three categories: no amplification (1-5 copies of the gene present per nucleus in $>50 \%$ of cancer cells); low amplification (6-10 copies of the gene, or a small gene cluster, present per nucleus in $>50 \%$ cancer cells); amplification (>10 copies, or large clusters, of the gene present per nucleus in $>50 \%$ cancer cells). The scores were subsequently grouped into two categories: no amplification and amplification. The whole extension of the core has been evaluated counting a mean of 1 nuclei per sample.

\section{Statistical analysis}

Categorical variables were analysed by $\chi^{2}$ test or Fisher's exact test when appropriate. The sensitivity and specificity of CISH were calculated using FISH as the gold standard. The level of significance was set to $5 \%$ for all tests. Statistical analysis was performed by SPSS software, V.17.0 (SPSS, Chicago, Illinois, USA).

\section{RESULTS}

\section{Clinicopathological results}

Clinicopathological and molecular information is described in table 1 . The sample comprised 52 cases of OSCC (40 male, 12 female) with mean ages of 56.3 years (range from 16 to 80 ). The T-staging and
$\mathrm{N}$-staging of the tumours were described according to the AJCC (American Joint Committee on Cancer)/ UICC (Union for International Cancer Control) classification for oral cavity carcinomas. ${ }^{9}$ Malignancy grade was as follows: $17(32.7 \%)$ well-differentiated, 14 (26.9\%) moderately differentiated and $21(40.4 \%)$ poorly differentiated tumours. The most common affected sites were the tongue and/or floor of the mouth $(75 \%)$; the majority of these lesions presented nodal involvement and were classified as poorly differentiated. Smokers comprised $81 \%$ of the patients, of which $18.8 \%$ revealed the consumption of more than 20 cigarettes/day. Alcohol habit was reported by $64.3 \%$ of the patients. A tendency of the smokers to present high-grade tumours was observed, chiefly when the consumption was above 20 cigarettes/day $(p<0.05)$. The mean of follow-up was 6 months.

\section{Immunohistochemistry, FISH and CISH results}

The pattern of the immunoexpression was a distinctive brown staining in the cytoplasmic membrane of the neoplastic cells, and $28(53.8 \%)$ cases were positive (figure 1A). CISH detected gene amplification in $3(5.8 \%)$ cases and FISH in 8 cases $(15.4 \%$ ) (figure 1B,C). Amplification detected by CISH and FISH without protein overexpression occurred in $2(3.8 \%)$ cases. One $(1.9 \%)$ case showed amplification detected by CISH and FISH and protein overexpression concomitantly. Five $(9.6 \%)$ cases revealed FISH amplification and protein overexpression without CISH amplification.

EGFR expression and amplification (CISH and FISH) were more frequent in low-grade tumours, but without significance $(p>0.05)$. Neither EGFR expression nor FISH results showed association with clinicopathological features. Amplification detected by CISH was associated with T3-T4 status $(\mathrm{p}=0.02)$. There was no association between protein expression and gene amplification; however, six of eight cases amplified by FISH showed positive EGFR staining. The three cases, considered amplified by CISH, also showed amplification in FISH assay, indicating a sensitivity of $37.5 \%$ and $100 \%$ specificity of CISH after receiver operating characteristic curve analysis.

\section{DISCUSSION}

Clinical trials suggest an interesting activity of EGFR inhibitors as a treatment for HNSCC. ${ }^{10} 11$ However, some issues need to be addressed yet, as to how best to evaluate EGFR expression or whether there is a correlation between EGFR expression and patient prognosis. ${ }^{12}$

EGFR protein overexpression has been reported in $70-90 \%$ of HNSCC, and the incidence of gene amplification has been demonstrated in about $17-31 \%$. Some authors have found that EGFR overexpression and amplification were associated with poor tumour differentiation and worse prognosis in HNSCC. ${ }^{4}{ }^{10}{ }^{13-15}$ However, in this present study, and as demonstrated in others, ${ }^{16} 17$ 
Table 1 Clinicopathological features, EGFR immunoexpression and CISH/FISH status of the cases

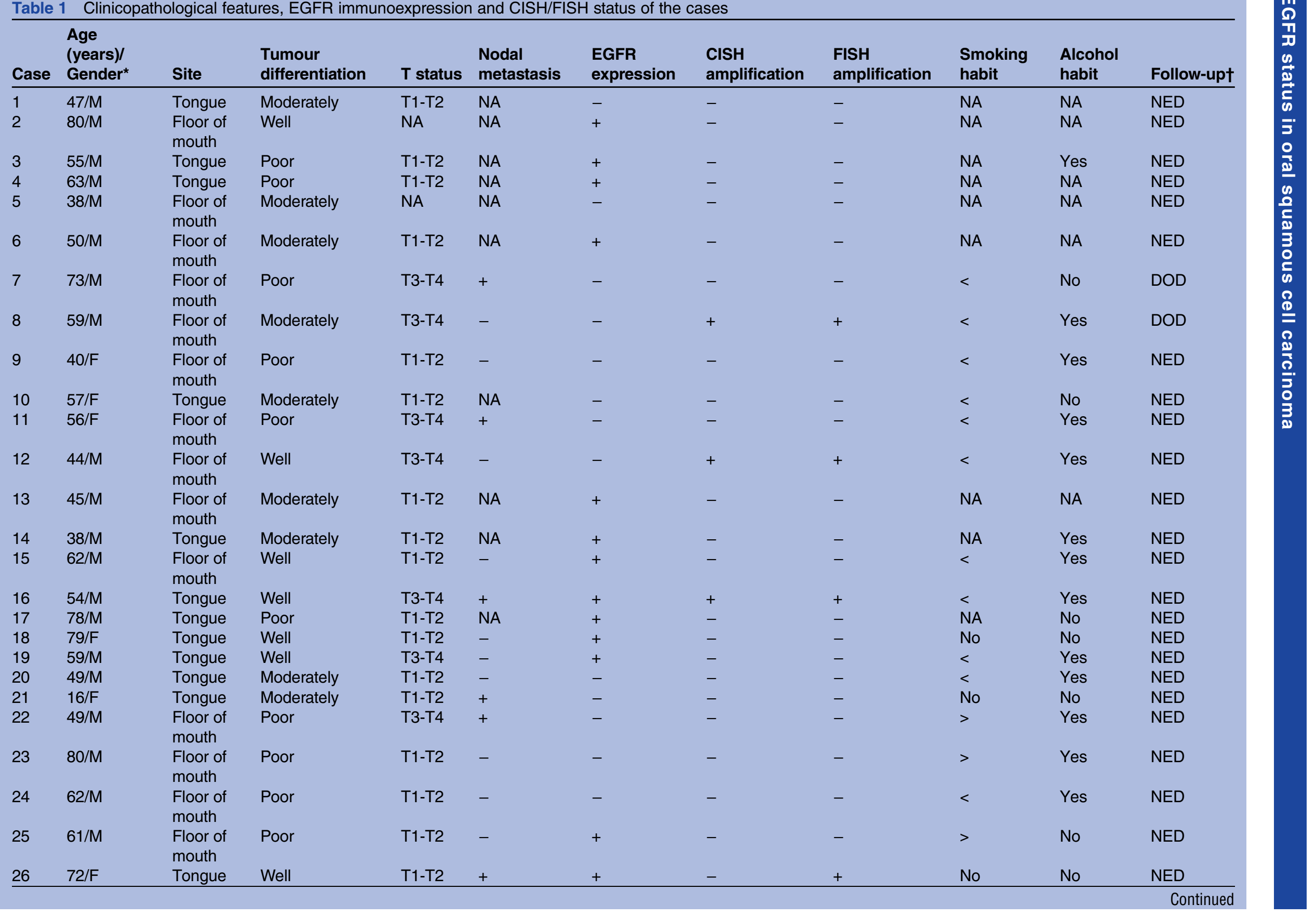




\begin{tabular}{|c|c|c|c|c|c|c|c|c|c|c|c|}
\hline Case & $\begin{array}{l}\text { Age } \\
\text { (years)/ } \\
\text { Gender* }\end{array}$ & Site & $\begin{array}{l}\text { Tumour } \\
\text { differentiation }\end{array}$ & T status & $\begin{array}{l}\text { Nodal } \\
\text { metastasis }\end{array}$ & $\begin{array}{l}\text { EGFR } \\
\text { expression }\end{array}$ & $\begin{array}{l}\text { CISH } \\
\text { amplification }\end{array}$ & $\begin{array}{l}\text { FISH } \\
\text { amplification }\end{array}$ & $\begin{array}{l}\text { Smoking } \\
\text { habit }\end{array}$ & $\begin{array}{l}\text { Alcohol } \\
\text { habit }\end{array}$ & Follow-upt \\
\hline 27 & $78 / F$ & Tongue & Well & $\mathrm{T} 1-\mathrm{T} 2$ & - & + & - & + & No & No & NED \\
\hline 28 & $72 / F$ & Tongue & Poor & $\mathrm{T} 1-\mathrm{T} 2$ & + & - & - & - & No & No & DOD \\
\hline 29 & $48 / \mathrm{M}$ & Tongue & Poor & T3-T4 & + & - & - & - & No & No & NED \\
\hline 30 & $52 / F$ & Tongue & Poor & $\mathrm{T} 1-\mathrm{T} 2$ & + & - & - & - & $<$ & Yes & NED \\
\hline 31 & $46 / \mathrm{M}$ & Tongue & Poor & T3-T4 & + & - & - & - & $<$ & Yes & NED \\
\hline 32 & $61 / \mathrm{M}$ & Tongue & Poor & T3-T4 & + & - & - & - & $>$ & Yes & NED \\
\hline 33 & $63 / \mathrm{M}$ & Tongue & Moderately & $\mathrm{T} 1-\mathrm{T} 2$ & + & + & - & - & $<$ & Yes & NED \\
\hline 34 & $69 / \mathrm{M}$ & $\begin{array}{l}\text { Floor of } \\
\text { mouth }\end{array}$ & Poor & T3-T4 & + & + & - & - & $>$ & No & NED \\
\hline 35 & $45 / \mathrm{M}$ & $\begin{array}{l}\text { Floor of } \\
\text { mouth }\end{array}$ & Well & NA & NA & + & - & - & $<$ & Yes & NED \\
\hline 36 & $58 / \mathrm{M}$ & $\begin{array}{l}\text { Floor of } \\
\text { mouth }\end{array}$ & Moderately & T3-T4 & + & + & - & - & $<$ & Yes & NED \\
\hline 37 & $52 / \mathrm{M}$ & Tongue & Well & $\mathrm{T} 1-\mathrm{T} 2$ & + & + & - & - & No & No & NED \\
\hline 38 & $64 / \mathrm{M}$ & $\begin{array}{l}\text { Floor of } \\
\text { mouth }\end{array}$ & Moderately & $\mathrm{T} 1-\mathrm{T} 2$ & - & + & - & - & NA & NA & DOD \\
\hline 39 & 49/M & Tongue & Well & $\mathrm{T} 1-\mathrm{T} 2$ & + & + & - & + & NA & NA & NED \\
\hline 40 & $51 / M$ & Gum & Moderately & NA & NA & + & - & + & NA & Yes & NED \\
\hline 41 & $40 / F$ & Palate & Well & $\mathrm{T} 1-\mathrm{T} 2$ & NA & - & - & - & NA & Yes & NED \\
\hline 42 & $54 / \mathrm{M}$ & Gum & Well & $\mathrm{T} 1-\mathrm{T} 2$ & NA & - & - & - & NA & Yes & NED \\
\hline 43 & $44 / \mathrm{M}$ & Gum & Poor & NA & NA & + & - & + & NA & Yes & NED \\
\hline 44 & $51 / \mathrm{M}$ & Gum & Poor & $\mathrm{T} 1-\mathrm{T} 2$ & - & - & - & - & NA & Yes & NED \\
\hline 45 & $51 / \mathrm{M}$ & Gum & Well & $\mathrm{T} 1-\mathrm{T} 2$ & NA & - & - & - & NA & NA & NED \\
\hline 46 & $68 / \mathrm{M}$ & Palate & Poor & $\mathrm{T} 1-\mathrm{T} 2$ & - & + & - & - & NA & No & NED \\
\hline 47 & $62 / \mathrm{M}$ & Gum & Well & $\mathrm{T} 1-\mathrm{T} 2$ & NA & + & - & - & NA & Yes & NED \\
\hline 48 & $62 / F$ & Gum & Well & $\mathrm{T} 1-\mathrm{T} 2$ & - & + & - & - & $<$ & No & DOD \\
\hline 49 & $44 / \mathrm{M}$ & Palate & Poor & T3-T4 & + & + & - & - & $>$ & Yes & NED \\
\hline 50 & $77 / M$ & Gum & Poor & NA & NA & + & - & - & NA & NA & NED \\
\hline 51 & $53 / F$ & $\begin{array}{l}\text { Buccal } \\
\text { mucosa }\end{array}$ & Well & $\mathrm{T} 1-\mathrm{T} 2$ & + & + & - & - & No & No & NED \\
\hline 52 & $48 / \mathrm{M}$ & Gum & Moderately & T3-T4 & + & - & - & - & $<$ & Yes & DOD \\
\hline
\end{tabular}



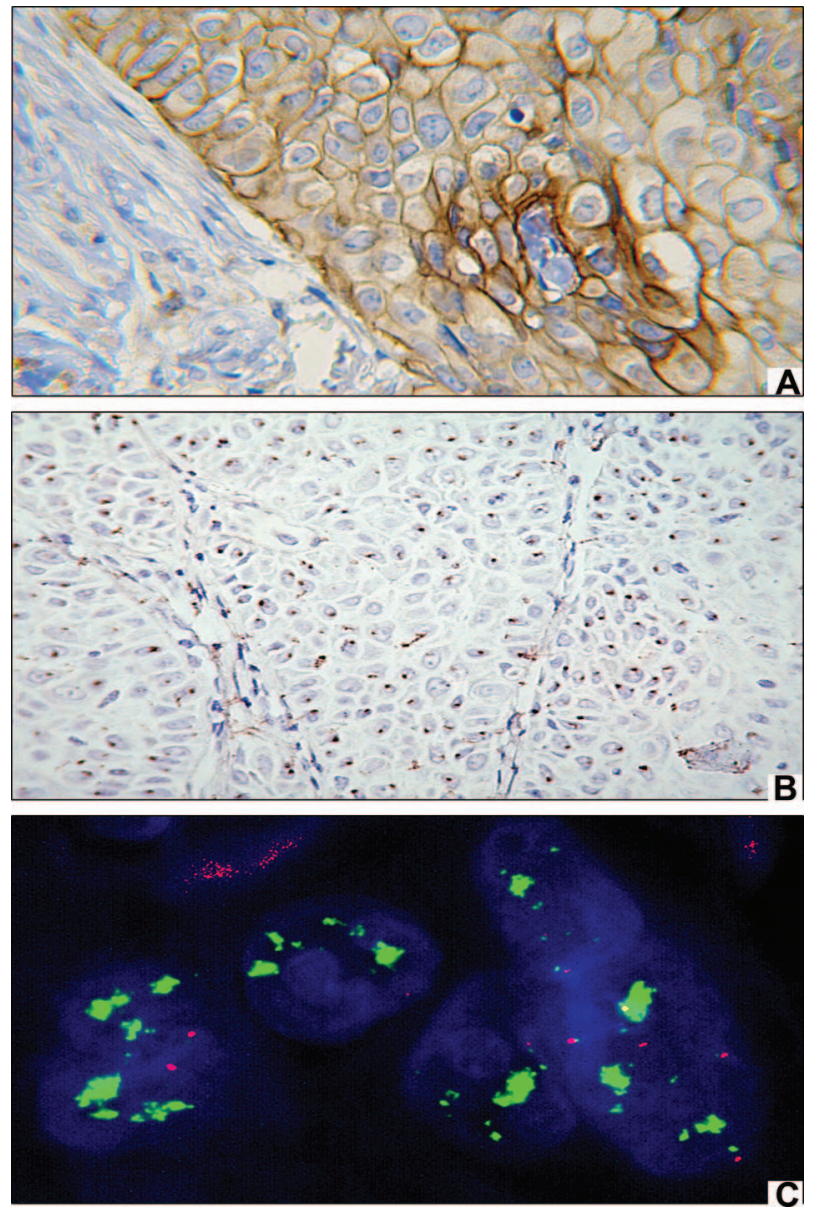

Figure 1 Epidermal growth factor receptor (EGFR) protein expression and gene amplification in oral squamous cell carcinoma. (A) Positive staining in the membrane of neoplastic cells ( $\times 400$ magnification). (B) Amplification of EGFR detected by chromogenic in situ hybridization $(\times 400$ magnification). (C) Amplification of EGFR detected by fluorescence in situ hybridization (green signal clusters represent the amplification of the EGFR gene, and red signals indicate the centromeric region of chromosome 7$)(\times 1000$ magnification).

most of the EGFR-positive lesions presented as low-grade tumours, revealing no association with patient outcome. Furthermore, EGFR overexpression has been considered a protective factor against locoregional recurrence and is related to an increased radiosensitivity. ${ }^{15}$ Baumeister et $a l^{18}$ found that high EGFR levels in normal oral mucosa render the cells less sensitive to carcinogens, and this increase might be a physiological response to permanent carcinogen impact.

In this study, we used a convenience sample, taking into account that OSCC demonstrates an increase of 42 to $58 \%$ in EGFR. In a previous study, we have already demonstrated EGFR expression in $50 \%$ of OSCC. ${ }^{16}$ Many cases of that previous study were employed in the present one. Regarding the TMA method, Monteiro et $a l^{8}$ demonstrated that the use of two 1.5-mm cores offers some advantages, such as a lower probability of sample lost, especially in heterogeneous tumours.
In addition, the authors demonstrated a strong correlation of Ki-67 and EGFR markers between the dual core TMA and the whole sections of OSCC. ${ }^{8}$ However, in our study, we used one $1 \mathrm{~mm}$ core from each case in view of the small size of the incisional biopsy samples.

Szabó et $a l^{14}$ give a reasonable explanation for these variable results concerning EGFR protein detection. They investigate in HNSCG samples different epitopespecific antibodies covering the entire EGFR protein. These antibodies recognised epitopes at the extracellular region close to the ligand-binding domain, membrane-proximal extracellular region, intracellular domain and the phosphotyrosine autophosphorylation site on the EGFR tyrosine kinase domain. ${ }^{14}$ Just EGFR intracellular domain detection was associated with a worse prognosis in HNSCC. EGFR extracellular domain detection showed no clinical association. Including this study, there were various studies that did not find any association between EGFR expression and tumour behaviour $^{151819}$ and used antibodies with affinity to the extracellular domain of EGFR.

High-grade tumours were frequently observed in advanced stages (T3-T4 and metastatic nodes), which however commonly revealed gene amplification, as found by Huang et $a l,{ }^{10}$ occurring in well-differentiated tumours. This incongruence might indicate that EGFR amplification has an uncertain impact in OSCC behaviour, as described by Tsiambas et $a l^{20}$

We compared the detection of EGFR amplification by CISH and FISH techniques. Unlike other studies, we found a substantial discrepancy between these techniques. Considering FISH as the gold standard technique, CISH demonstrated a great specificity but a low sensibility, since just $37.5 \%$ of amplified FISH cases were detected by CISH. It should be due to the fact that evaluation of borderline signals could be more challenging in CISH. Its signal is highly affected by preanalytical factors in which low signal intensity or high background staining might be observed, thus impairing a correct interpretation. $^{21-23}$ This finding precludes the use of CISH as a tool for detection of EGFR gene amplification in OSCC.

Surprisingly, gene amplification correlated poorly with protein expression. Hence, as observed by others, some cases revealed protein overexpression in spite of gene amplification, as well as the inverse. ${ }^{19} \quad 20$ 24-26 Takes et $a t^{27}$ suggested that this might be the result of different methodologies to assess the status of EGFR and preanalytical issues. For Szabó et $a l,{ }^{14}$ differences in the specificity of antibodies might be responsible for it. They showed that EGFR gene amplification correlated with protein expression just when an antibody recognising the intracellular domain of the protein was used. The use of antibodies against the extracellular domains did not show any correlation. We could hypothesise that EGFR expression not only does not depend on the gene copy number, but also that the rise in protein expression does not predict specific gene deregulation. It indicates 
that other mechanisms that are not subject to EGFR amplification might be involved in the rise in EGFR expression in OSCC.

We conclude that there is no association between EGFR protein expression and EGFR gene copy number in OSCG using the methods employed in this study. Neither EGFR overexpression nor EGFR copy number was associated with the clinicopathological characteristics of OSCC. EGFR might still be useful as a predictive marker, although for this, it is necessary to establish which is the best method to evaluate EGFR status and its relationship to response to therapy.

\section{Author affiliations}

${ }^{1}$ Department of Oral Surgery and Pathology, School of Dentistry, Universidade Federal de Minas Gerais, Belo Horizonte, Minas Gerais, Brazil

${ }^{2}$ Laboratory of Medical Genomics, Centro Internacional de Pesquisa e Ensino (CIPE)—Cancer Hospital AC Camargo-Fundação Antônio Prudente, São Paulo, Brazil

${ }^{3}$ Department of Anatomic Pathology, Cancer Hospital AC Camargo-Fundação Antônio Prudente, São Paulo, Brazil

Acknowledgements The authors are grateful to Dr Geovanni Dantas Cassali, Universidade Federal de Minas Gerais, for his scientific assistance.

Contributors We declare that each author has contributed sufficiently to the intellectual content of the submission. VFB, FOGN and SFS participated in the data acquisition, carried out the experiments and helped in the drafting of the manuscript. MCFA participated in the concept of the study, interpretation of the data and drafting of the manuscript. RMR helped in the experiments and in their critical revision, as well as in the drafting of the manuscript. All authors read and approved the final manuscript.

Funding This study was supported by the Research Foundation of the State of Minas Gerais (FAPEMIG-CDS APQ-1580; PPM 0516-11), the Fundação de Amparo à Pesquisa do Estado de São Paulo (FAPESP) and the National Council for Scientific and Technological Development (CNPq).

Competing interests None.

Ethics approval Ethics approval was provided by the Research Ethics Committee of Universidade Federal de Minas Gerais (87/07).

Provenance and peer review Not commissioned; externally peer reviewed.

Data sharing statement There are no additional data available.

\section{REFERENCES}

1. Herbst RS. Review of epidermal growth factor receptor biology. Int $J$ Radiat Oncol Biol Phys 2004;59(2 Suppl):21-6.

2. Erman M. Molecular mechanisms of signal transduction: epidermal growth factor receptor family, vascular endothelial growth factor family, Kit, platelet-derived growth factor receptor, Ras. J BUON 2007;12(Suppl 1):S83-94.

3. Rogers SJ, Harrington KJ, Rhys-Evans $\mathrm{P}$, et al. Biological significance of c-erbB family oncogenes in head and neck cancer. Cancer Metastasis Rev 2005;24:47-69.

4. Sheikh Ali MA, Gunduz M, Nagatsuka $\mathrm{H}$, et al. Expression and mutation analysis of epidermal growth factor receptor in head and neck squamous cell carcinoma. Cancer Sci 2008;99:1589-94.

5. Tanner M, Gancberg D, Di Leo A, et al. Chromogenic in situ hybridization: a practical alternative for fluorescence in situ hybridization to detect HER-2/neu oncogene amplification in archival breast cancer samples. Am J Pathol 2000;157:1467-72.

6. Sáez A, Andreu FJ, Seguí MA, et al. HER-2 gene amplification by chromogenic in situ hybridisation $(\mathrm{CISH})$ compared with fluorescence in situ hybridisation (FISH) in breast cancer-A study of two hundred cases. Breast 2006;15:519-27.

7. Diniz-Freitas MT, Garcia-Caballero J, Antunez-Lopez J, et al. Pharmacodiagnostic evaluation of EGFR expression in oral squamous cell carcinoma. Oral Dis 2007;13:285-90.

8. Monteiro LS, Diniz-Freitas M, Garcia-Caballero T, et al. EGFR and $\mathrm{Ki}-67$ expression in oral squamous cell carcinoma using tissue microarray technology. J Oral Pathol Med 2010;39:571-8.

9. Lip and oral cavity. American Joint Committee on Cancer: AJCC Cancer Staging Manual New York: Springer, 2002:23-32.

10. Huang SF, Cheng SD, Chien HT, et al. Relationship between epidermal growth factor receptor gene copy number and protein expression in oral cavity squamous cell carcinoma. Oral Oncol 2012;48:67-72.

11. Rivera F, García-Castaño A, Vega N, et al. Cetuximab in metastatic or recurrent head and neck cancer: the EXTREME trial. Expert Rev Anticancer Ther 2009;9:1421-8.

12. Arteaga CL. Epidermal growth factor receptor dependence in human tumors: more than just expression? Oncologist 2002;7:31-9.

13. Ulanovski $D$, Stern $Y$, Roizman $P$, et al. Expression of EGFR and Cerb-B2 as prognostic factors in cancer of the tongue. Oral Oncol 2004;40:532-7.

14. Szabó B, Nelhubel GA, Kárpáti A, et al. Clinical significance of genetic alterations and expression of epidermal growth factor receptor (EGFR) in head and neck squamous cell carcinomas. Oral Oncol 2011;47:487-96.

15. Smith BD, Smith GL, Carter D, et al. Molecular marker expression in oral and oropharyngeal squamous cell carcinoma. Arch Otolaryngol Head Neck Surg 2001;127:780-5.

16. Bernardes VF, Gleber-Netto FO, Sousa SF, et al. Clinical significance of EGFR, Her-2 and EGF in oral squamous cell carcinoma: a case control study. J Exp Clin Cancer Res 2010;29:40.

17. Yamada T, Takagi M, Shioda S. Evaluation of epidermal growth factor receptor in squamous cell carcinoma of the oral cavity. Oral Surg Oral Med Oral Pathol 1992;73:67-70.

18. Baumeister $P$, Heinrich $K$, Märte $M$, et al. The impact of EGFR stimulation and inhibition on BPDE induced DNA fragmentation in oral/oropharyngeal mucosa in vitro. Oral Oncol 2011;47:1141-7.

19. Nakata Y, Uzawa N, Takahashi K, et al. EGFR gene copy number alteration is a better prognostic indicator than protein overexpression in oral tongue squamous cell carcinomas. Eur J Cancer 2011;47:2364-72

20. Tsiambas E, Stavrakis I, Lazarist AC, et al. Evaluation of epidermal growth factor receptor gene and chromossome 7 alterations in squamous cell carcinoma of the larynx, using chromogenic in situ hybridization on tissue microarrays. The $J$ Laryngol Otol 2007;12:563-70.

21. Brügmann A, Lelkaitis $\mathrm{G}$, Nielsen $\mathrm{S}$, et al. Testing HER2 in breast cancer: a comparative study on BRISH, FISH, and IHC. Appl Immunohistochem Mol Morphol 2011;19:203-11.

22. Mayr D, Heim S, Weyrauch $\mathrm{K}$, et al. Chromogenic in situ hybridization for Her-2/neu-oncogene in breast cancer: comparison of a new dual-colour chromogenic in situ hybridization with immunohistochemistry and fluorescence in situ hybridization. Histopathology 2009;55:716-23.

23. Gong Y, Gilcrease M, Sneige N. Reliability of chromogenic in situ hybridization for detecting HER-2 gene status in breast cancer: comparison with fluorescence in situ hybridization and assessment of interobserver reproducibility. Mod Pathol 2005;18:1015-21.

24. Tsiambas E, Manaios L, Papanikolopoulos C, et al. Chromogenic in situ hybridization analysis of epidermal growth factor receptor gene/ chromosome 7 numerical aberrations in hepatocellular carcinoma based on tissue microarrays. Pathol Oncol Res 2009;15:511-20.

25. Buckley AF, Burgart LJ, Sahai V, et al. Epidermal growth factor receptor expression and gene copy number in conventional hepatocellular carcinoma. Am J Clin Pathol 2008;129:245-51.

26. Shia J, Klimstra DS, Li AR, et al. Epidermal growth factor receptor expression and gene amplification in colorectal carcinoma: an immunohistochemical and chromogenic in situ hybridization study. Mod Pathol 2005;18:1350-6.

27. Takes RP, Baatenburg de Jong RJ, Schuuring E, et al. Differences in expression of oncogenes and tumor suppressor genes in different sites of head and neck squamous cell. Anticancer Res 1998; 18(6 B):4793-800. 